\title{
FAKTOR-FAKTOR YANG MEMPENGARUHI KINERJA PERBANKAN SYARIAH DI INDONESIA (Studi Pada Bank Umum Syariah yang Terdaftar di Otoritas Jasa Keuangan Periode 2015 - 2019)
}

\author{
Desi Angraini Dasopang \\ Fakultas Ekonomi, Universitas Muhammadiyah Riau \\ e-mail: desiangrainidas@email.ac.id
}

\begin{abstract}
ABSTRAK
Tujuan penelitian ini adalah Untuk mengetahui pengaruh Islamic Corporate Social Responsibility, reputasi, Shariah Governance, dan zakat terhadap kinerja perbankan syariah pada Bank Umum Syariah yang terdaftar di Otoritas Jasa Keuangan (OJK) periode 2015-2019. Populasi dalam penelitian ini adalah perbankan syariah pada Bank Umum Syariah yang terdaftar di Otoritas Jasa Keuangan (OJK) periode 2015-2019 yang berjumlah 14 bank umum syariah. Pemilihan sampel menggunakan purposive sampling, sehingga sampel dalam penelitian ini berjumlah 11 bank syariah. Sumber data yang digunakan dalam penelitian ini adalah data sekunder yang bersifat kuantitatif. Analisis data menggunakan analisis regresi linier berganda. Hasil penelitian menunjukkan Islamic Corporate Social Responsibility berpengaruh terhadap kinerja perbankan syariah, reputasi tidak berpengaruh terhadap kinerja perbankan syariah, Shariah Governance berpengaruh terhadap kinerja perbankan syariah, dan zakat berpengaruh terhadap kinerja perbankan syariah.
\end{abstract}

Kata Kunci : Islamic Corporate Social Responsibility, reputasi, Shariah Governance, zakat

\section{ABSTRACT}

The purpose of this study was to determine the effect of Islamic Corporate Social Responsibility, reputation, Shariah Governance, and zakat on the performance of Islamic banking at Sharia Commercial Banks registered with the Financial Services Authority (OJK) for the 2015-2019 period. The population in this study is Islamic banking at Islamic Commercial Banks registered with the Financial Services Authority (OJK) for the 2015-2019 period, totaling 14 Islamic commercial banks. The sample selection used purposive sampling, so the sample in this study amounted to 11 Islamic banks. Sources of data used in this study is secondary data that is quantitative. Data analysis used multiple linear regression analysis. The results show that Islamic Corporate Social Responsibility affects the performance of Islamic banking, reputation does not affect the performance of Islamic banking, Shariah Governance affects the performance of Islamic banking, and zakat has an effect on the performance of Islamic banking.

Keywords : Islamic Corporate Social Responsibility, reputasi, Shariah Governance, zakat

\section{PENDAHULUAN}

Penilaian kinerja suatu entitas bisnis maupun manajemen bisnis dewasa ini tidak hanya diukur dari aspek keuangan tetapi juga non keuangan.Aspek keuangan dapat berupa rasio-rasio keuangan dan aspek non keuangan dapat berupa tanggung jawab sosial perusahaan dan tata kelola perusahaan. Dengan mengukur kinerja maka bisa diketahui tingkat keberhasilan perusahaan dalam menjalankan usahanya selama kurun waktu tertentu. Terkait dengan kinerja keuangan, berdasarkan data statistik perbankan Indonesia menurut Otoritas Jasa Keuangan (OJK) laba bersih perbankan syariah mencatat laba sebesar Rp1,10 triliun pada tahun 2015 dan 
pada tahun $2016 \mathrm{Rp} 2,09$ triliun. Laba bersih perbankan syariah hingga akhir 2017 mencapai Rp 3,08 triliun. Nilai tersebut melonjak 47,36\% dibandingkan perolehan pada akhir 2016 yang mencapai Rp 2,09 triliun. Laba bersih perbankan syariah tahun 2018 sebesar 5,1 triliun, sedangkan untuk tahun 2019 laba bersih perbankan syariah mencapai 7,8 triliun.

Dari kasus tersebut menunjukkan bahwa kinerja perbankan syariah bisa dikatakan cukup baik, namun hal tersebut tidak diimbangi dengan reputasi yang baik karena reputasi terkait dengan kepercayaan nasabah untuk bermitra dengan bank syariah. Karena jika ditelisik lebih dalam, perbankan syariah memiliki potensi pertumbuhan yang baik di Indonesia dengan mayoritas penduduk Indonesia yang beragama Islam yaitu sekitar $87,18 \%$ dari total penduduk Indonesia (www.bps.go.id, 2016). Tetapi hanya sekitar 5,86\% atau sekitar 17 juta penduduk dari total penduduk Indonesia yang memiliki rekening bank syariah (Linangkung, 2017). Angka tersebut menunjukkan bahwa pertumbuhan jumlah bank syariah yang terus meningkat belum diikuti dengan jumlah nasabah yang banyak.Hal tersebut membuktikan bahwa minat masyarakat untuk bermitra dengan bank syariah masih sangat rendah. Reputasi juga dapat mempengaruhi kinerja bank. Hal itu karena, reputasi perusahaan dapat mempengaruhi dukungan masyarakat terhadap bank dan akses bank terhadap sumber daya yang ia perlukan. Semakin baik bank mengelola reputasinya, maka semakin baik bank dalam mendapatkan sumber dayanya, seperti: mempertahankan pemegang sahamnya, menambah pelanggan untuk memakai produk dan jasanya, membangun kemitraan dengan pemasok, merekrut pegawai potensial, mempertahankan pegawai, yang kesemuanya dapat diraih dengan biaya modal yang lebih ringan (Louisot dan Rayner, 2010). Oleh karena itu, dapat pula diasumsikan bahwa reputasi dan kinerja saling berkaitan. Reputasi yang baik, akan memudahkan bank dalam meningkatkan kinerjanya.

Saat ini islamic corporate social responsibility sedang menjadi tema yang banyak dibicarakan tidak hanya di negara-negara yang penduduknya mayoritas muslim, tetapi telah menjadi objek utama penelitian diberbagai negara termasuk di negara yang penduduknya menganut kepercayaan lain dan tidak menjalankan hukum syariah sebagai dasar etika dalam bisnis (Johan dan Eke, 2016). Menurut Chapra (1992) dalam Arifin dan Wardani (2016), di dalam syariat islam suatu kegiatan tidak hanya dimaksudkan untuk memenuhi kebutuhan yang bersifat material saja, tetapi juga harus dilandasi tanggung jawab terhadap agama. Karena itu perusahaan khususnya perbankan syariah yang berdiri berlandaskan prinsip-prinsip syariah dituntut untuk mempertanggungjawabkan kegiatan usahanya kepada Allah Subhanahu Wa Ta'ala. Dengan demikian pengungkapan Islamic Corporate Social Responsibility dapat dijadikan media pertanggungjawaban perusahaan kepada Allah Subhanahu Wa Ta'ala dan masyarakat. Sidik dan Reskino (2016) menjelaskan bahwa konsep islamic corporate social responsibility ini melengkapi dasar pemikiran yang cukup kuat mengenai pentingnya inisiatif corporate social responsibility jika dipandang dari sudut pandang keislaman. Islamic corporate social responsibility merupakan konsep tanggung jawab sosial perusahaan yang berdimensi ekonomi islam, legal islam, etika islam, dan filantropi islam berdasarkan nilai-nilai kesilaman yang ada pada Al-quran dan hadits.

Faktor ketiga yang mempengaruhi kinerja perbankan syariah adalah shariah governance. Islamic Financial Services Board (IFSB) menjelaskan definisi Sharia Governance merupakan seperangkat peraturan kelembagaan dan organisasi dimana lembaga keuangan syariah dapat memastikan bahwa terdapat pandangan independen tentang kepatuhan syariah melalui proses penerbitan fatwa syariah yang relevan, penyebaran informasi fatwa dan review internal kepatuhan syariah. Shariah governance merupakan konsep tata kelola yang unik dan khusus bagi perusahaan atau lembaga keuangan yang menawarkan produk dan jasa yang sesuai dengan prinsip syariah. Shariah governance hakekatnya menjadi komplementer dari sistem tata kelola perusahaan yang baik (good corporate governance) yang sudah ada yang fungsi utamanya untuk melakukan review atas kepatuhan syariah atas seluruh aktivitas perusahaan baik sebelum terjadinya transaksi maupun setelah terjadinya transaksi. Untuk menjalankan fungsi tersebut, sistem shariah governance harus memiliki tiga, yaitu Dewan Pengawas Syariah (DPS), opini kepatuhan syariah dan proses review syariah. 
Berdasarkan Peraturan Bank Indonesia No. 11/33/PBI/2009 pasal 49 tentang pelaksanaan Good Corporate Governance bagi Bank Umum Syariah (BUS) dan Unit Usaha Syariah (UUS), rapat Dewan Pengawas Syariah wajib diselenggarakan paling kurang satu kali dalam satu bulan dan pengambilan keputusan rapat Dewan Pengawas Syariah dilakukan berdasarkan musyawarah mufakat. Faktor terakhir adalah Zakat merupakan bagian dari konsep CSR yang akan memberikan panduan pada perusahaan untuk memperhatikan kepentingan sosial disamping kepentingan perusahaan itu sendiri. Pemerintah menyadari bahwa jika pengelolaan zakat dilakukan dengan baik, transparan, dan bertanggung jawab, maka banyak persoalan sosial dan ekonomi dalam masyarakat dapat terpecahkan.Perlu diketahui bahwa zakat yang diwajibkan atas badan usaha tidak dimaksudkan untuk membebani badan usaha secara berlebihan dan mengancam keberlangsungan hidup perusahaan. Menurut UU. No 17 Tahun 2000, tentang Pajak Penghasilan, Pasal 4 ayat 3 "pengeluaran zakat dinyatakan sebagai penguranganpenghasilan kena pajak bagi pihak yang mengeluarkan zakat". Peraturan ini diharapkan kondisi keuangan badan usaha pembayar zakat tidak terbebani secara berlebihan.

\section{TINJAUAN LITERATUR DAN PERUMUSAN HIPOTESIS}

\section{Kinerja Perusahaan}

Menurut Rivai dan Fawzi (2004) Kinerja perusahaan merupakan hasil kerja yang dapat dicapai oleh seseorang atau kelompok orang dalam suatu perusahaan sesuai dengan wewenang dan tanggungjawab masing-masing dalam upaya pencapaian tujuan perusahaan secara legal, tidak melanggar hukum, dan tidak bertentangan dengan moral dan etika.

\section{Islamic Corporate Social Responsibility (ICSR)}

Menurut Sidik dan Reskino, (2016) Islamic Corporate Social Responsibility (ICSR)adalah sebuah konsep Corporate Social Responsibility Islami yang dikembangkan dari Corporate SocialResponsibility konvensional. Ajaran dalam Islam selama ini telah memiliki konsep amal/filantropi yangmana identik dengan konsep filantropi dalam konvensional. Hal ini terlihat dari ajaran untuk berzakat, berinfak, bersedekah, memberi makan orang miskin, tidak berbuat kerusakan, serta memberikan pinjaman kepada orang yang membutuhkan tanpa mengharap imbalan (qard).

\section{Reputasi Perusahaan}

Reputasi perusahaan menurut Susanto (2013) memiliki pengertian sebagai berikut:“Aset dan kekayaan yang memberikan keunggulan kompetitif karena perusahaan seperti ini akan dianggap sebagai yang andal, kredibel, dapat dipercaya dan bertanggung jawab untuk karyawan, pelanggan, pemegang saham dan pasar keuangan"

\section{Shariah Governance}

IFSB menjelaskan tentang definisi sharia governance adalah seperangkat pengaturan kelembagaan dan organisasi dimana lembaga keuangan syariah dapat memastikan bahwa terdapat pandangan independen tentang kepatuhan syariah melalui proses penerbitan fatwa syariah yang relevan, penyebaran informasi fatwa dan review internal kepatuhan syariah.

\section{Hipotesis}

Pengaruh Islamic Corporate Social Responsibility Terhadap KinerjaPerbankan Syariah

Menurut Drever et al (2007) dalam Sidik dan Reskino (2016) Signalling theory memandng bahwa pengungkapan yang informatif dapat membawa perusahaan pada nilai yang lebih baik. Hal tersebut tentunya menjadi motivasi bagi bank syariah dalam mengungkapkan inisiatif Islamic Corporate Social Responsibility, dengan harapan menerima respon yang baik yang dapat meningkatkan nilai perusahaannya di pasar. 
Seperti yang diungkapkan oleh Arshad, et.al (2012) bahwa penerapan ICSR dipercaya dapat meningkatkan kinerja keuangan, dimana stakeholdercenderung menanamkan modalnya pada bank syariah yang melakukan aktivitas ICSR. Karena bagi stakeholder bank syariah yang melakukan aktivitas ICSR berpotensi dalam menghasilkan laba yang lebih besar dibandingkan yang tidak, sehingga kedepannya bank akan mampu meningkatkan kinerjanya. Oleh karena itu menurut Arshad et.al (2012) menyatakan bahwa ICSR memiliki pengaruh positif dan signifikan terhadap kinerja perbankan syariah. Berdasarkan uraian diatas maka dapat dirumuskan hipotesis sebagai berikut:

\section{H1 : Islamic Corporate Social Responsibility berpengaruh terhadap Kinerja Keuangan} Perbankan Syariah Di Indonesia.

\section{Pengaruh Reputasi Terhadap Kinerja Perbankan Syariah}

Menurut Louisot dan Rayner (2010) reputasi berpengaruh terhadap kinerja perbankan. Hal ini disebabkan karena reputasi dapat mempengaruhi dukungan masyarakat terhadap bank dan akses bank terhadap sumber daya yang ia perlukan. Semakin baik bank mengelola reputasinya, maka semakin baik bank dalam mendapatkan sumber dayanya, seperti: mempertahankan pemegang sahamnya, menambah pelanggan untuk memakai produk dan jasanya, membangun kemitraan dengan pemasok, merekrut pegawai potensial, mempertahankan pegawai, yang kesemuanya dapat diraih dengan biaya modal yang lebih ringan.

reputasi memberikan hasil positif pada kinerja perusahaan, menarik investor keuangan, biaya produksi yang lebih rendah, meningkatkan kemampuan kompetitif dan corporate citizenship yang baik diantara karyawan. Menurut Roberts dan Dowling (2002), perusahaan dengan reputasi yang baik lebih mampu mempertahankan profit dari waktu ke waktu. Berdasarkan uraian diatas maka dapat dirumuskan hipotesis sebagai berikut:

H2 : Reputasi berpengaruh terhadap Kinerja Keuangan Perbankan Syariah di Indonesia.

\section{Pengaruh Shariah Governance Terhadap Kinerja Perbankan Syariah}

Menurut Hasan (2011) menjelaskan bahwa tata kelola perbankan syariah (shariah governance) merupakan salah satu bahasan yang signifikan dalam perkembangan lembaga keuangan islam sekarang ini. Tata kelola perusahaan, terutama dalam paradigma islam dianggap penting karena mengutamakan kejujuran, integritas, transparansi, akuntabilitas dan tanggung jawab diantara semua stakeholders dalam sebuah organisasi. Mereka juga menjelaskan bahwa shariah governance merupakan hal yang paling esensi dalam lingkup keuangan islam untuk membangun dan memelihara kepercayaan stakeholders lainnya bahwa seluruh transaksi dan operasi perbankan syariahsudah sesuai dengan prinsip-prinsip syariah dalam hal untuk meningkatkan kinerja perbankan syariah. Shariah governance dalam penelitian ini diindikatorkan dengan indikator jumlah rapat. Berdasarkan uraian di atas maka dapat dirumuskan hipotesis sebagai berikut:

\section{H3 : Shariah Governance berpengaruh terhadap Kinerja Keuangan Perbankan Syariah} Di Indonesia.

\section{Pengaruh Zakat Terhadap Kinerja Perbankan Syariah.}

Zakat merupakan salah satu rukun Islam yang hukumnya wajib bagi setiap muslim yang merdeka dan memiliki harta kekayaan sampai dengan jumlah tertentu yang telah mencapai nisab. Menurut pandangan Islam, Allah adalah pemilik mutlak alam semesta dan isinya, sehingga harta kekayaan yang dimiliki manusia hanyalah titipan yang bersifat sementara, di mana manusia diberi kekuasaan untuk mengelolanya.Zakat merupakan bagian dari konsep CSR yang akan memberikan panduan pada perusahaan untuk memperhatikan kepentingan sosial disamping kepentingan perusahaan itu sendiri. Kedermawanan perusahaan diwadahi dan dilambangkan sebagai zakat pengusaha maupun perusahaan. Zakat merupakan suatu kewajiban bagi umat muslim yang tergolong mampu. 
Dalam praktiknya, sebagian dari bank syariah besar di Indonesia telah melaksanakan zakat sebagai salah satu dari nilai bisnisnya. Selain sebagai bentuk pemenuhan kewajiban dalam perspektif agama, membayar zakat juga merupakan cara bank syariah dalam menjaga citra perusahaannya, sehingga mampu menciptakan reputasi yang baik dari stakeholder. Berdasarkan uraian diatas maka dapat dirumuskan hipotesis sebagai berikut:

H4 : Zakat berpengaruh terhadap Kinerja Keuangan Perbankan Syariah di Indonesia.

\section{METODE PENELITIAN}

Populasi dalam penelitian ini adalah perbankan syariah yang terdaftar di Otoritas Jasa Keuangan periode tahun 2015-2019.. Populasi dalam penelitian ini perusahaan Indek LQ45 yang berjumlah 45 perusahan. Dalam penelitian ini, sampel yang terpilih adalah Bank Umum Syariah yang terdaftar di Otoritas Jasa Keuangan dari tahun 2015 sampai dengan tahun 2019 secara berturut-turut dan memiliki kriteria tertentu yang mendukung penelitian.Pemilihan sampel menggunakan purposive sampling adalah karena tidak semua sampel memiliki kriteria yang sesuai dengan yang penulis tentukan, Dalam hal ini jumlah sampel yang digunakan oleh peneliti sebanyak 13 Bank Umum Syariah yang terdaftar di Otoritas Jasa Keuangan periode 2015-2019. Data yang digunakan dalam penelitian ini adalah data sekunder. Metode analisis data yang digunakan dalam penelitian ini adalah analisis regresi linier berganda.

\section{HASIL DAN PEMBAHASAN}

\section{Hasil Statisktik Deskriptif Variabel Penelitian}

Selengkapnya mengenai hasil statistik deskriptif penelitian dapat dilihat pada Tabel 1 berikut ini.

\begin{tabular}{lrrrrr}
\multicolumn{7}{c}{ Tabel 1. Hasil Uji Statistik Deskriptif } \\
Descriptive Statistics & & \\
\hline & N & \multicolumn{1}{c}{ Minimum } & Maximum & \multicolumn{1}{c}{ Mean } & Std. Deviation \\
\hline ROA (Y) & 55 & -8.09 & 13.60 & 1.3329 & 3.46821 \\
ICSR (X1) & 55 & 34.880 & 79.070 & 56.66018 & 10.170090 \\
REPUTASI (X2) & 55 & .000004 & .120155 & .01814291 & .029384711 \\
INSG (X3) & 55 & .50 & 1.00 & .9273 & .17790 \\
ZAKAT (X4) & 55 & -10868 & 34991 & 4892.18 & 8354.880 \\
Valid N (listwise) & 55 & & & & \\
\hline
\end{tabular}

Berdasarkan data dari Tabel 4.1 di atas dapat dijelaskan sebagai berikut:

1. Variabel kinerja keuangan yang diukur dengan ROA memiliki nilai minimum $-8,09 \%$, nilai maksimum 13,6 \%, rata-rata 1,3329 \%dan standar deviasi 3,4682. Dengan standar deviasi sebesar 3,4682, dapat diartikan adanya variasi yang terdapat dalam ROA.

2. Variabel Islamic Corporate Social Responsibility(ICSR) memiliki nilai minimum $-34,880$ $\%$, nilai maksimum 79,070 \%, rata-rata 56,66018\%dan standar deviasi 10.170090. Dengan standar deviasi sebesar 10.170090 yang lebih kecil dari rata-rata, dapat diartikan tidak adanya variasi yang terdapat dalam ICSR. 
3. Variabel reputasi memiliki nilai minimum -0.000004 nilai maksimum 0.120155 , rata-rata 0.01814291dan standar deviasi 0.029384711. Dengan standar deviasi sebesar .029384711 yang lebih besar dari rata-rata, dapat diartikan adanya variasi yang terdapat dalam reputasi.

4. Variabel Shariah Governancememiliki nilai minimum 0,50 nilai maksimum 1,00, rata-rata 0,9273 dan standar deviasi 0,17790. Dengan standar deviasi sebesar 0,17790 yang lebih kecil dari rata-rata, dapat diartikan tidak adanya variasi yang terdapat dalam Shariah Governance

5. Variabel zakat memiliki nilai minimum -10868 nilai maksimum 34991, rata-rata 4892,18 dan standar deviasi 8354.880. Dengan standar deviasi sebesar 8354.880 yang lebih besar dari rata-rata, dapat diartikanadanya variasi yang terdapat dalam zakat.

\section{Hasil Uji Normalitas}

Pengujian normalitas dapat dilihat dari Tabel 3 berikut ini:

Tabel 3. Hasil Uji Normalitas dengan Kolmogorov-Smirnov

One-Sample Kolmogorov-Smirnov Test

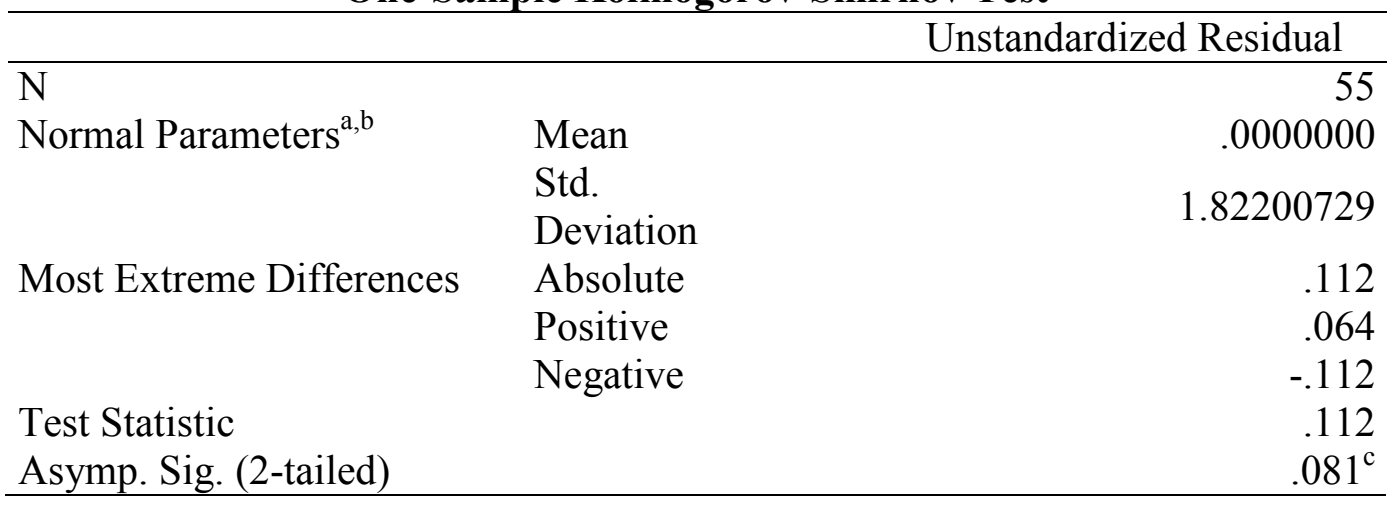

Berdasarkan uji Kolmogorov smirnov pada Tabel 3 diperoleh nilai signifikan sebesar 0,081 angka ini lebih besar dari 0,05, maka dapat disimpulkan bahwa data berdistribusi normal.

\section{Hasil Uji Multikolinearitas}

Hasil uji multikolinearitas dapat dilihat di Tabel 4 berikut:

Tabel 4. Hasil Uji Multikolinearitas

\begin{tabular}{llccc}
\hline & & \multicolumn{2}{c}{ Collinearity Statistics } \\
\cline { 3 - 4 } Model & & \multicolumn{2}{c}{ Tolerance } & VIF \\
\hline 1 & (Constant) & & 1.105 \\
& ICSR (X1) & .905 & 1.005 \\
& REPUTASI (X2) & .995 & 1.196 \\
& INSG (X3) & .836 & 1.145 \\
\hline
\end{tabular}

Dari tabel di atas, dapat dilihat bahwa VIF untuk seluruh variabel bebas $<10$ dan begitu juga nilai tolerance $>0,10$. Hal ini dapat disimpulkan bahwa model regresi tersebut bebas dari multikolinearitas. 


\section{Hasil Uji Heterokedastisitas}

Hasil uji heteroskedastisitas dapat dilihat pada Gambar 1 berikut ini.

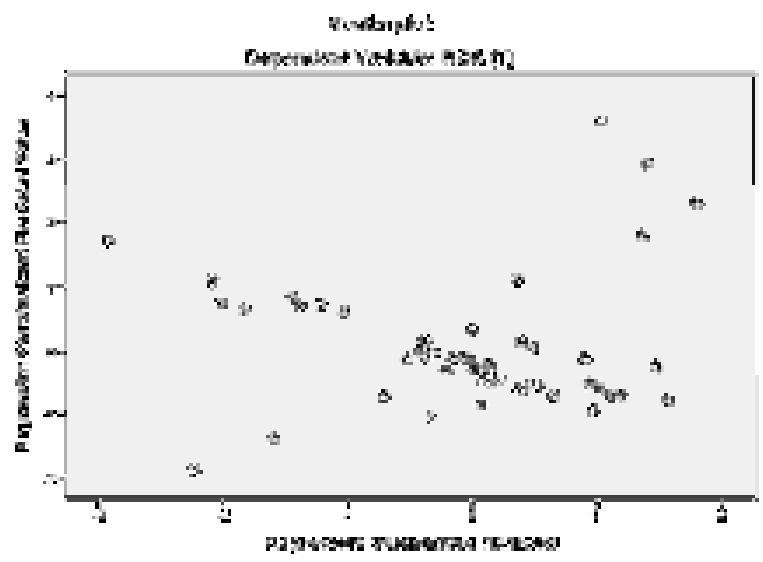

Dari Gambar 1 dapat dilihat bahwa titik-titik menyebar antara sumbu X dan Y, artinya tidak terjadi heteroskedastisitas, sehingga dapat disimpulkan bahwa persyaratan uji heteroskedastisitas dapat terpenuhi untuk pengujian hipotesis.

\section{Hasil Uji Autokorelasi}

Hasil uji autokorelasi dapat dilihat pada Tabel 5

Tabel 5. Hasil Uji Autokorelasi

Model Summary ${ }^{\text {b }}$

\begin{tabular}{lrrrrr}
\hline Model & R & R Square & $\begin{array}{c}\text { Adjusted R } \\
\text { Square }\end{array}$ & $\begin{array}{c}\text { Std. Error of the } \\
\text { Estimate }\end{array}$ & Durbin-Watson \\
\hline 1 & $.851^{\mathrm{a}}$ & .724 & .702 & 1.89349 & 1.150 \\
\hline
\end{tabular}

Berdasarkan Tabel 5 dapat diketahui nilai Durbin Watson sebesar 1,150 ini berarti nilai Durbin Watson berada pada angka -2 sampai +2 , maka dapat disimpulkan bahwa dalam penelitian ini tidak terdapat autokorelasi. Artinya bahwa variabel independent dalam penelitian ini tidak terganggu atau terpengaruhi oleh variabel pengganggu.

\section{Hasil Uji Regresi Regresi Linier Berganda}

Hasil uji regresi linier berganda dapat dilihat pada Tabel 6 berikut ini.

Tabel 6. Hasil Uji Model Regresi Linier Berganda

Coefficients $^{\mathrm{a}}$

\begin{tabular}{llccccc}
\hline & & \multicolumn{2}{c}{$\begin{array}{c}\text { Unstandardized } \\
\text { Coefficients }\end{array}$} & \multicolumn{2}{c}{$\begin{array}{c}\text { Standardized } \\
\text { Coefficients }\end{array}$} & \\
\cline { 2 - 5 } Model & B & Std. Error & Beta & T & Sig. \\
\hline 1 & (Constant) & 4.012 & 2.308 & & 1.738 & .088 \\
& & & & & & \\
& ICSR (X1) & 5.291 & 2.499 & .165 & 2.117 & .039 \\
& & & & & \\
& REPUTASI (X2) & 12.589 & 8.791 & .107 & 1.432 & .158 \\
& INSG (X3) & 7.553 & 1.584 & .387 & 4.768 & .000 \\
& ZAKAT (X4) & .463 & .197 & .557 & 7.004 & .000 \\
\hline
\end{tabular}

a. Dependent Variable: ROA (Y) 
Berdasarkan Tabel 6 diperoleh persamaan regresi sebagai berikut:

$$
Y=4,012+5,291 X_{1}+12,589 X_{2}+7,553+0,463 X_{4}
$$

Keterangan hasil pengujian di atas dijelaskan sebagai berikut:

a. Nilai Konstanta sebesar 4,012 menunjukkan bahwa apabila variabel independen yaitu ICSR, Reputasi, INSG, dan Zakat dianggap konstan (bernilai 0) maka nilai variabel dependen yaitu nilai perusahaan adalah sebesar 4,012

b. Koefisien regresi (b1) ICSR (X1) mempunyai nilai positif sebesar 5,291, Hal ini dapat diartikan bahwa setiap kenaikan ICSR menyebabkan ROA naik sebesar 5,291

c. Koefisien regresi (b2) Reputasi (X2) mempunyai nilai positif sebesar 12,589 Hal ini dapat diartikan bahwa setiap kenaikan reputasi menyebabkan ROA naik sebesar 12,589

d. Koefisien regresi (b3) INSG (X3) mempunyai nilai positif sebesar 7,553, Hal ini dapat diartikan bahwa setiap kenaikan INSG menyebabkan ROA naik sebesar 7,553.

e. Koefisien regresi (b4) zakat (X4) mempunyai nilai positif sebesar 0,463, Hal ini dapat diartikan bahwa setiap kenaikan zakat menyebabkan ROA naik sebesar 0,463.

\section{Hasil Uji t (Uji Hipotesis)}

Berdasarkan hasil analisis regresi linier barganda pada Tabel 6 Dapat dijelaskan masingmasing uji hipotesis sebagai berikut:

1. Pengaruh Islamic Corporate Social Responsibility $\left(\mathrm{X}_{1}\right)$ terhadap Kinerja Keuangan (Y) Hipotesis 1

Hasil regresi pengaruh Islamic Corporate Social Responsibility $\left(\mathrm{X}_{1}\right)$ terhadap kinerja keuangan (Y) memberikan nilai $\mathrm{t}_{\text {hitung }}$ sebesar 4,486 nilai ini lebih besar dari $\mathrm{t}$ tabel $t_{\text {tabel }} 2,009$ dengan nilai $P_{\text {value }} 0,039<0,05$. Nilai $t$ positif sehingga Ho ditolak dan $H_{1}$ diterima artinya variabel Islamic Corporate Social Responsibility $\left(\mathrm{X}_{1}\right)$ berpengaruh signifikan terhadap kinerja keuangan (Y)

2. Pengaruh Reputasi $\left(\mathrm{X}_{2}\right)$ terhadap Kinerja Keuangan $(Y)$ Hipotesis 2

Hasil regresi pengaruh reputasi $\left(\mathrm{X}_{2}\right)$ terhadap kinerja keuangan $(\mathrm{Y})$ memberikan nilai $\mathrm{t}_{\text {hitung }}$ sebesar 1,432 nilai ini lebih kecil dari $t$ tabel $t_{\text {tabel }} 2,009$ dengan nilai $P_{\text {value }} 0,158>0,05$. Nilai $\mathrm{t}$ positif sehingga Ho diterima dan Haditolak artinya variabel reputasi $\left(\mathrm{X}_{2}\right)$ tidak berpengaruh terhadap kinerja keuangan $(\mathrm{Y})$

3. Pengaruh Shariah Governance $\left(\mathrm{X}_{3}\right)$ terhadap Kinerja Keuangan $(\mathrm{Y})$ Hipotesis 3

Hasil regresi pengaruh Shariah Governance $\left(\mathrm{X}_{3}\right)$ terhadap kinerja keuangan (Y) memberikan nilai $t_{\text {hitung }}$ sebesar 4,768 nilai ini lebih besardari t tabel $t_{\text {tabel }} 2,009$ dengan nilai $\mathrm{P}_{\text {value }} 0,000<0,05$. Nilai t positif sehingga Ho ditolak dan Haditerima artinya variabel Shariah Governance $\left(\mathrm{X}_{3}\right)$ berpengaruh signifikan terhadap kinerja keuangan (Y)

4. Pengaruh Zakat $\left(X_{4}\right)$ terhadap Kinerja Keuangan (Y) Hipotesis 4

Hasil regresi pengaruh zakat $\left(\mathrm{X}_{4}\right)$ terhadap kinerja keuangan $(\mathrm{Y})$ memberikan nilai $\mathrm{t}_{\text {hitung }}$ sebesar 7,004 nilai ini lebih besardari $t$ tabel $t_{\text {tabel }} 2,009$ dengan nilai $P_{\text {value }} 0,000<0,05$. Nilai $\mathrm{t}$ positif sehingga Ho ditolak dan Haditerima artinya variabel zakat $\left(\mathrm{X}_{4}\right)$ berpengaruh signifikan terhadap kinerja keuangan $(\mathrm{Y})$

\section{Hasil Uji Koefisien Determinasi}

Tabel 7. Hasil Uji Koefisien Determinasi

\begin{tabular}{llrrrr} 
& \multicolumn{3}{c}{ Model Summary } \\
\hline Model & R & R Square & $\begin{array}{c}\text { Adjusted R } \\
\text { Square }\end{array}$ & $\begin{array}{c}\text { Std. Error of the } \\
\text { Estimate }\end{array}$ \\
\hline 1 & $.851^{*}$ & .724 & .702 & 1.89349 \\
\hline
\end{tabular}


Berdasarkan Tabel 7 dapat diketahui bahwa nilai adjusted $R$ Squareyang diperoleh sebesar 0,702 atau 70,2 \%. Artinya, ICSR, Reputasi, INSG, dan Zakat dapat mempengaruhi kinerja perusahaan sebesar 70,2\%. Sedangkan sisanya $29,8 \%$ dipengaruhi oleh faktor lain.

\section{PEMBAHASAN}

\section{Pengaruh Islamic Corporate Social Responsibility Terhadap Kinerja Perbankan Syariah}

Berdasarkan hasil pengujian hipotesis diperoleh bahwa Islamic Corporate Social Responsibilityberpengaruh terhadap kinerja keuangan perbankan syariah. Hal ini menunjukkan bahwa semakin banyak pengungkapan ICSR perusahaan maka semakin meningkat kinerja keuangan perbankan syariah. Hasil penelitian ini membuktikan bahwa pengungkapan Islamic corporate social responsibilitydapat menjadi salah satu faktor yang dapat mempengaruhi kenerja keuangan. Berpengaruhnya ICSR terhadap kinerja keuangan perbankan syariah disebabkan karena ICSR merupakan dapat menjadi salah satu informasi bagi investor ataupun masyarakat untuk mempercayai bank syariah dengan demikian kinerja keuangan bank syariah menjadi meningkat.

Menurut Thahirah et.al, (2016). pengungkapan Islamic corporate social responsibility menjadi suatu halyang sangat penting bagi kinerja lembaga keuangan syariah. Karena lembaga keuangan syariah yang mengungkapkan ICSR dengan baik akan dipandang sebagai entitas yang dapat dipercaya oleh masyarakat muslim dalam menyalurkan dana mereka Hal ini menunjukkan bahwa inisiatif ICSR bisa dijadikan sebuah strategi bisnis oleh perbankan syariah dalam menghadapi tuntutan persaingan bisnis yang ketat. Hasil penelitian ini sesuai denganSignalling theory memandng bahwa pengungkapan yang informatif dapat membawa perusahaan pada nilai yang lebih baik. Hal tersebut tentunya menjadi motivasi bagi bank syariah dalam mengungkapkan inisiatif Islamic Corporate Social Responsibility, dengan harapan menerima respon yang baik yang dapat meningkatkan nilai perusahaannya di pasar (Drever et al (2007) dalam Sidik dan Reskino (2016).

Hasil penelitian ini juga sesuai dengan yang diungkapkan oleh Arshad, et.al (2012) bahwa penerapan ICSR dipercaya dapat meningkatkan kinerja keuangan, dimana stakeholder $r$ cenderung menanamkan modalnya pada bank syariah yang melakukan aktivitas ICSR. Karena bagi stakeholder bank syariah yang melakukan aktivitas ICSR berpotensi dalam menghasilkan laba yang lebih besar dibandingkan yang tidak, sehingga kedepannya bank akan mampu meningkatkan kinerjanya. Oleh karena itu menurut Arshad et.al (2012) menyatakan bahwa ICSR memiliki pengaruh positif dan signifikan terhadap kinerja perbankan syariah.

\section{Pengaruh Reputasi Terhadap Kinerja Perbankan Syariah}

Berdasarkan hasil pengujian hipotesis diperoleh reputasi tidak berpengaruh terhadap kinerja keuangan perbankan syariah. Hal ini menunjukkan bahwa tinggi atau rendahnya reputasi tidak mampu meningkatkan kinerja keuangan perbankan syariah. Tidak berpengaruhnya reputasi terhadap kinerja keuangan kemungkinan disebabkan ke 11 bank syariah yang menjadi sampel merupakan bank umum syariah di Indonesia yang sudah dipercaya oleh masyarakat untuk menanamkan dananya, sehingga reputasi bukan merupakan salah satu faktor yang dapat mempengaruhi kinerja keuangan perbankan syariah.

Hasil penelitian ini tidak sejalan dengan penelitian Louisot dan Rayner (2010) reputasi berpengaruh terhadap kinerja perbankan. Hal ini disebabkan karena reputasi dapat mempengaruhi dukungan masyarakat terhadap bank dan akses bank terhadap sumber daya yang ia perlukan. Semakin baik bank mengelola reputasinya, maka semakin baik bank dalam mendapatkan sumber dayanya, seperti: mempertahankan pemegang sahamnya, menambah pelanggan untuk memakai produk dan jasanya, membangun kemitraan dengan pemasok, merekrut pegawai potensial, mempertahankan pegawai, yang kesemuanya dapat diraih dengan biaya modal yang lebih ringan. 


\section{Pengaruh Shariah GovernanceTerhadap Kinerja Perbankan Syariah}

Berdasarkan hasil pengujian hipotesis diperoleh Shariah Governanceberpengaruh terhadap kinerja keuangan perbankan syariah. Hal ini menunjukkan bahwa semakin baik shariah governance maka semakin mudah bank syariah dalam meningkatkan kinerjanya, karena untuk membangun dan memelihara kepercayaan stakeholders seluruh transaksi dan operasi perbankan syariah harus sesuai dengan prinsip-prinsip syariah. Menurut Hasan (2011) menjelaskan bahwa tata kelola perbankan syariah (shariah governance) merupakan salah satu bahasan yang signifikan dalam perkembangan lembaga keuangan islam sekarang ini. Tata kelola perusahaan, terutama dalam paradigma islam dianggap penting karena mengutamakan kejujuran, integritas, transparansi, akuntabilitas dan tanggung jawab diantara semua stakeholders dalam sebuah organisasi. Mereka juga menjelaskan bahwa shariah governance merupakan hal yang paling esensi dalam lingkup keuangan islam untuk membangun dan memelihara kepercayaan stakeholders lainnya bahwa seluruh transaksi dan operasi perbankan syariahsudah sesuai dengan prinsip-prinsip syariah dalam hal untuk meningkatkan kinerja perbankan syariah.

\section{Pengaruh ZakatTerhadap KinerjaPerbankan Syariah}

Berdasarkan hasil pengujian hipotesis diperoleh zakatberpengaruh terhadap kinerja keuangan perbankan syariah. Hal ini menunjukkan bahwa dengan mengeluarkan zakat perusahaan dapat meningkatkan kinerja keuangannya. Hal ini disebabkan zakat merupakan salah satu ICSR sehingga menjadi sinyal positif bagi masyarakat yang dapat menyebabkan meningkatnya kinerja keuangan perusahaan. disamping itu zakat salah satu cara untuk mendistribusikan pendapatan secara adil dan merata tersebut adalah dengan membayar dan mendistribusikan zakat. Khursid et al. (2014) menyatakan bahwa zakat merupakan salah satu poin yang perlu diperhatikan dan dilaksanakan perusahaan sebagai praktik filantropinya dalam hal mengedepankan unsur-unsur syariah dalam Corporate Social Responsibility nya.

Hasil penelitian ini sejalan dengan signalling theory, zakat yang dibayar, dikelola, didistribusikan, serta diungkapkan perusahaan dalam CSR akan menjadi sinyal positif dimata masyarakat sehingga membantu perusahaan dalam meraih simpati dan dukungan dari para stakeholder serta memberi dampak positif bagi reputasi perusahaan termasuk meningkatkan kinerja perusahaan.

\section{KESIMPULAN}

Islamic Corporate Social Responsibility berpengaruh terhadap kinerja perbankan syariah, reputasi tidak berpengaruh terhadap kinerja perbankan syariah, Shariah Governance berpengaruh terhadap kinerja perbankan syariah, dan zakat berpengaruh terhadap kinerja perbankan syariah

\section{DAFTAR PUSTAKA}

Arifin, J. dan Wardani, E.A. (2016). Islamic corporate social responsibility disclosure,reputasi, dan kinerja keuangan: Studi pada bank syariah di Indonesia. Jurnal Akuntansi \& Auditing Indonesia. Vol. 20 No. 1.

Arshad, R., Othman, S., dan Othman, R. (2012). Islamic corporate social responsibility, corporate reputation and performance. International Journal of Social, Behavioral, Educational, Economic, Business and Industrial Engineering Vol.6,No.4.

Hasan. 2011. Analisis Industri Perbankan Syariah di Indonesia. Jurnal DinamikaEkonomi Pembangunan Vol.1, No.1. Universitas Wahid Hasyim. Semarang.

Louisot, J.P., dan Rayner, J. 2010. Managing Risk to Reputation: From Theory toPractice. 
Linangkung, Erfanto.(2016). Penetrasi perbankan syariah masih sangat rendah.Diakses 29 Maret 2018.https://ekbis.sindonews.com.

Sidik, Ichwan dan Reskino. 2016. Pengaruh Zakat dan ICSR terhadap Reputasi dan Kinerja. Jurnal Simposium Nasional Akuntansi XIX.

Susanto, A.B. 2013. 60 Management Gems Applying Management Wisdom in Life.Jakarta: Gramedia Pustaka Utama. 